\title{
LARGE THEROPOD TEETH FROM THE EOCENOMANIAN OF NORTHEASTERN BRAZIL AND THE OCCURRENCE OF SPINOSAURIDAE
}

\author{
MANUEL ALFREDO MEDEIROS \\ Departamento de Biologia, UFMA, Campus do Bacanga, 65080-040, São Luís, MA, Brazil. alf@elo.com.br
}

\begin{abstract}
Theropoda teeth can show sufficiently distinct features to be, in some cases, considered as confident diagnostic material. In this work, 275 complete or fragmentary teeth, collected at the Laje do Coringa site (Alcântara Formation), have been analyzed. In some of them, the typical spinosaurine morphology is present while in others an intriguing morphology was observed: teeth combining typical features of spinosaurines (smooth carinae with wrinkles on its base) with other characters as absolutely smooth enamel and basal cross section gently compressed labio-lingually. These different forms typify two morphotypes; a number of other teeth present variation that links them by a morphologic gradient. Morphotype 1 records the presence of spinosaurine dinosaurs in the Eocenomanian of northeastern Brazil and morphotype 2 may represent a new species of Theropoda, unknown by skeletal remains, and perhaps closely related to the spinosaurine form recorded.
\end{abstract}

Key words: Dinosaurs, Spinosauridae, Cretaceous, Cenomanian, Alcântara Formation.

RESUMO - Dentes de terópodes podem mostrar características suficientemente distintas para serem, em alguns casos, confiáveis como material diagnóstico. Neste trabalho, 275 dentes completos ou fragmentados, coletados no sítio Laje do Coringa (Formação Alcântara), foram analisados. Em alguns, a morfologia típica de espinossaurinos está presente, enquanto em outros uma intrigante morfologia foi observada: dentes combinando características típicas de espinossaurinos (carenas lisas com enrugamentos em sua base) com outras como esmalte absolutamente liso e seção basal levemente comprimida lábio-lingualmente. Estas formas diferentes tipificam dois morfótipos; vários outros dentes apresentam variação ligando-os por um gradiente morfológico. O morfótipo 1 registra a presença de dinossauros espinossaurinos no Eocenomaniano do nordeste do Brasil e o morfótipo 2 pode representar uma nova espécie de terópode, desconhecida por restos esqueletais, e talvez proximamente aparentada da forma de espinossaurino registrada.

Palavras-chave: Dinossauros, Spinosauridae, Cretáceo, Cenomaniano, Formação Alcântara.

\section{INTRODUCTION}

The Cretaceous dinosaurian faunas of South America are best known from Argentina and southern and southeastern Brazil (see Kellner \& Campos, 2000) largely because fossiliferous sites with dinosaur remains have rarely been reported in the vast regions of northern South America. The northeastern coastal Mesozoic basins of Brazil were formed as South America separated from Africa. Bearing thick Cretaceous sedimentary deposits, the São Luis Basin records paleoenvironments on a newly formed Atlantic coast (Aranha et al., 1990; Pedrão et al., 1993; Góes \& Rossetti, 2001).

The early Cenomanian stage is well represented in the dominantly sandy deposits of the Alcântara Formation, Itapecuru Group (Rossetti \& Truckenbrodt, 1997), which was dated through palynological analysis (Pedrão et al., 1993). These deposits are wide spread across a vast area in northern Maranhão State and, in São Marcos Bay, São Luís Basin, the Alcântara Formation crops out extensively along the coast. It records a Cretaceous transitional environment - chiefly a tidal estuarine system on a wave dominated tidal coast (Rossetti \& Truckenbrodt, 1997). Within most of this coastal sequence no significant accumulation of fossil bones has been found. However, on the Cajual island, situated in the westernmost edge of the bay ( $\left.2^{\circ} 28^{\prime} 46,6^{\prime} \mathrm{S} ; 44^{\circ} 28^{\prime} 23,8^{\prime \prime} \mathrm{W}\right)$, about $25 \mathrm{~km}$ distant of São Luís, an important exposure has been discovered. Laje do Coringa is a small and isolated site on a sandy beach at Cajual island (Figure 1), where well cemented conglomeratic layers have yielded a remarkable concentration of fossil material (Corrêa Martins, 1997) reworked from continental deposits.

Tides of more than $6 \mathrm{~m}$ continually undermine these hard layers redepositing them on the beach where many slabs remain intact but others disintegrate and release individual fossil fragments. Much information has recently been obtained from this fossiliferous site concerning its origin and the fauna of fishes and terrestrial tetrapods that lived in this region of Brazil (Vilas Bôas et al., 1999; Medeiros, 2001; Medeiros \& Vilas Bôas, 1999; Medeiros \& Schultz, 2001, 2002, 2004; Holz, 2003). 
As the study of the Laje do Coringa fauna advanced along with other sites of Itapecuru Group many authors claimed a striking resemblance with that of the mid-Cretaceous continental Saharan deposits (Medeiros \& Vilas Bôas, 1999; Dutra \& Malabarba, 2001; Medeiros \& Schultz, 2001, 2002; Pereira \& Medeiros, 2003; Castro et al., 2004). Medeiros \& Schultz (2002) argued that during Albian and Eocenomanian time northern Africa and northern South America shared the same paleoenvironmental conditions: a dominantly arid to semi-arid landscape (see Pedrão et al., 2003) with large size vegetation restricted to the fluvial systems, mainly estuaries, which supported the dinosaurian megafauna. Such conditions would be maintained by a seasonal climate with a short but stormy rainy season.

Thus far, the thousands of disarticulated and fragmentary fossil materials, mainly vertebral centra and teeth, collected at Laje do Coringa bone bed revealed titanosauromorphs and rebbachisaurid sauropod dinosaurs, as well as theropods Carcharodontosaurus Stromer, 1931, Spinosaurus Stromer, 1915, and Sigilmassasaurus Russell, 1996 (Vilas Bôas et al., 1999; Medeiros, 2001; Medeiros \& Schultz, 2001; 2002; 2004; Medeiros \& Vilas Bôas, 1999), and several skeletal elements that closely resembles those studied by Lapparent (1960) in the midCretaceous Continental Intercalar of the Central Sahara, but their taxonomic affinities remain unresolved (see Medeiros \& Schultz, 2002). Along with this dinosaurian fauna a rich record of fishes is documented in the Alcântara Formation, which includes midCretaceous north-African forms of Coelacanthid, Dipnoi, Neopterygii, Rajiformes, and Cladistia (Cunha \& Ferreira, 1980; Dutra \& Malabarba, 2001; Medeiros, 2001; Medeiros \& Schultz, 2001, 2002; Pereira \& Medeiros, 2003; Castro et al., 2004). Materials referred to marine reptiles have also recorded in the Alcântara Formation (Vilas Bôas \& Carvalho, 2001).
The occurrence of a spinosaurid dinosaur in Laje do Coringa site was based on isolated teeth and associated fauna (Medeiros \& Vilas Bôas, 1999; Medeiros \& Schultz, 2001, 2002), but previous occurrences in Cretaceous deposits of northeastern Brazil include cranial material (Kellner \& Campos, 1996; Martill et al., 1996).

This work focuses on an analysis of Theropoda teeth collected at the Laje do Coringa outcrop. Although sharing some features, they show significant variation in morphology, and the sample includes specimens with typical spinosaurine morphology. Alternative explanations for the occurrence are discussed. The material described here is housed in the fossil collection of the Universidade Federal do Maranhão (UFMA), in São Luis, Brazil.

\section{SYSTEMATICS}

THEROPODA Marsh, 1881

TETANURAE Gauthier, 1986

SPINOSAUROIDEA Stromer, 1915 sensu Sereno et al., 1998 SPINOSAURIDAE Stromer, 1915 sensu Sereno et al., 1998

(Figure 2)

Material. UFMA 1.20.070, UFMA 1.20.443, UFMA 1.20.444 SL. The sample as a whole assembles 275 complete or fragmentary teeth.

Description. UFMA 1.20 .070 is a complete tooth $80 \mathrm{~mm}$ long (Figures 2A1,A2); UFMA 1.20.443 is an almost complete tooth, lacking the tip, and measures $101 \mathrm{~mm}$ (Figures 2E1, E2). UFMA 1.20.444 SL is a superlot of 273 complete or fragmentary teeth selected among those collected at the Laje do Coringa site, and includes all other specimens cited in the text but UFMA 1.20.070

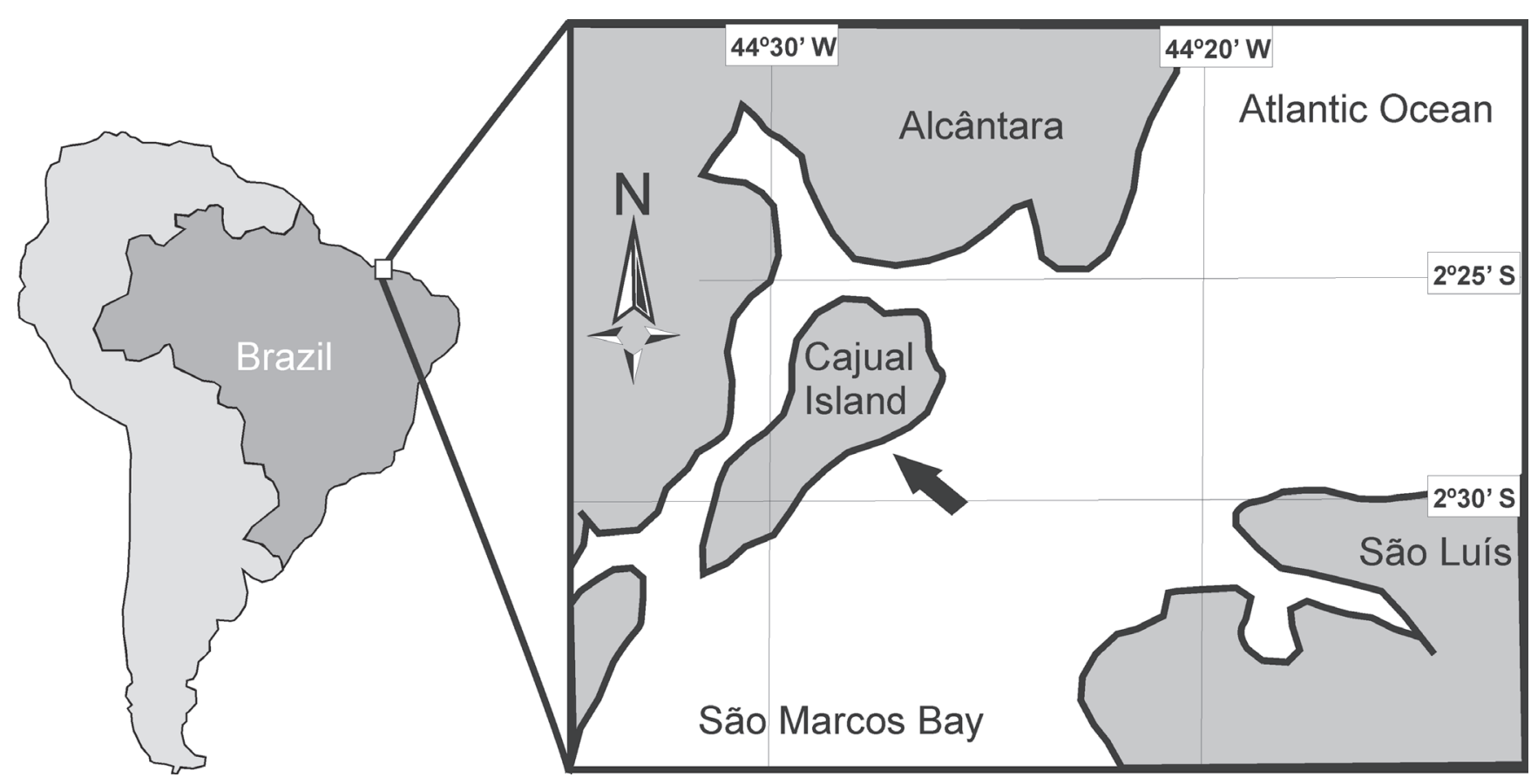

Figure 1. Localization of Cajual island in northeastern Brazil. Black arrow indicates the position of the bone bed Laje do Coringa on a sandy beach. 
and UFMA 1.20.443. The selection was made under the criteria of preservation quality and clear observance of morphological characters. All of these teeth are pointed and gently recurved. They bear non serrated carinae that divide the crown into two faces. Complete teeth assembled in superlot UFMA 1.20.444 SL vary between 13 and $98 \mathrm{~mm}$ in length, but some fragments may represent teeth that exceeded $100 \mathrm{~mm}$. Two semi-distinct morphotypes are present, linked by morphologic intermediates. At one extreme (morphotype 1, typified by UFMA 1.20.070) are teeth with nearly straight crowns with both faces (labial and lingual) showing longitudinal sub-facets (or flutes); rounded basal section and unserrated carinae with no enamel wrinkles at its base (Figures 2A1, A2, F). Morphotype 2 (typified by UFMA 1.20.443; Figures 2E1,E2, G) include teeth almost straight to gently curved, presenting smooth enamel with no longitudinal sub-facets at all, basal cross section varying from rounded to oval or even compressed labio-lingually. Some specimens corresponding to this morphotype present carinae with irregularly distributed enamel wrinkles at its base (Figure 2J). Carinae of both morphotypes are devoid of denticles, as all the other teeth sampled. Superlot UFMA 1.20.444 SL includes 25 teeth referable to morphotype 1, 95 referable to morphotype 2, and 153 intermediates.

Between the extreme morphotypes, a number of different feature combinations are recorded. So, the superlot UFMA 1.20.444 SL includes teeth showing variation as follows: basal cross section varies by degree from almost circular to compressed (Figures 2F, G, H, I); the surfaces of the crowns can be clearly to faintly facetted or absolutely smooth; the points of the teeth are rounded like those of crocodiles or sharply pointed; the carinae may vary from very low to expanded and sharp like a blade in both morphotypes. It is important to remark that, as far as the quality of the preserved enamel permits observation, carinae with associated wrinkles (Figure 2J) are present in the morphotype 2 and intermediary forms, including those with less markedly faceted faces, but are usually absent when the tooth morphology is similar to morphotype 1. Figure 2 shows some of these intermediary morphologies: B, median sized tooth with oval to gently compressed basal section (G), showing an extensively subfaceted lingual face (B1) and the labial one faintly faceted (B2), with both carinae expanded and markedly wrinkled at its base; $\mathrm{C}$, large tooth with gently compressed basal section $(\mathrm{H})$, presenting a faintly sub-faceted face $(\mathrm{C} 1)$ and the other one totally smooth $(\mathrm{C} 2)$, with sharply pointed distal end, and gently expanded carinae with faint wrinkles irregularly distributed at its base; D, median sized tooth compressed labio-lingually ( I), with both faces smooth (D1,2), expanded carinae and just a few wrinkles.

Discussion. Since the variation of feature combinations forms a gradient, morphotypes were defined as the most distinct combinations that represent its extremes. Teeth similar to those here described as morphotype 1 have also been found in northern Africa and Araripe Basin, Ceará, Brazil. They are considered as belonging to the highly specialized theropod clade Spinosauridae, which includes the African forms Spinosaurus aegyptiacus and Spinosaurus sp. (Stromer, 1915;
Bouaziz et al., 1988; Buffetaut, 1989, 1992; Kellner \& Mader, 1997) and the Brazilian species Irritator challengeri Martill et al., 1996 and Angaturama limai Kellner \& Campos, 1996. The teeth here described can not be referable to other spinosaurid forms as Baryonyx or Suchomimus (Charig \& Milner, 1997; Sereno et al., 1998) since the carinae are devoid of serrations. Spinosaurid dinosaurs were apparently a diverse group confidently known from Europe and mainly northern Africa and northern South America from the Early Cretaceous to the Cenomanian (Stromer, 1915; Charig \& Milner, 1997; Taquet \& Russell, 1998; Sereno et al., 1998; Kellner \& Campos, 1996; Medeiros \& Schultz, 2001, 2002; Sues et al., 2002; Machado \& Kellner, 2005).

In the sample here studied we can easily identify teeth (Figures 2A1, A2) with a morphology typical of Spinosaurus aegyptiacus and of Irritator challengeri (Stromer, 1915; Martill et al., 1996; Bouaziz et al., 1988; Kellner \& Mader, 1997; Sues et al., 2002). These two genera represent the sub-group Spinosaurinae that have teeth with nearly straight unserrated crowns (Sereno et al., 1998). The specimen shown in Figures 2B1 and B2, although presenting basal section gently compressed (Figure 2G), is quite similar in morphology to that of Irritator challengeri described and illustrated by Sues et al. (2002:539, fig. 5), including enamel wrinkles as described by those authors. Such wrinkles have never been recorded to Spinosaurus. These two genera may actually be very close related species; they could even belong to the same genus (Sues et al., 2002). Some authors consider Irritator challengeri a putative senior synonym of Angaturama limai (see Charig \& Milner, 1997; Sereno et al., 1998; Sues et al., 2002), but Machado \& Kellner (2005) see such interpretation as premature, supposing the possible occurrence of two spinosaurid forms in the Araripe deposits of northeastern Brazil. The spinosaurine form recorded by isolated teeth (morphotype 1) in Laje do Coringa remains to be determined.

Morphotype 2 is intriguing because shows characters present in spinosaurines - unserrated carinae and wrinkles at its base (see above), combined with totally smooth enamel surface, a feature uncommon to this group. Furthermore, some specimens included in this morphotype have rounded basal section, as in spinosaurines, while others tend to be gently compressed. Other similar forms found in the sample show faintly defined sub-facets usually on the lingual face. Yet, in some teeth the carinae are low, while in others it is expanded and sharp; eventually these different carinae are in the same tooth. When the 153 intermediates teeth are compared, a gradient of these different features is evident. If one aligns these teeth side by side, following the gradient, morphotype 1 , typical of spinosaurines, will progressively undergo modifications which will culminate in teeth of equivalent size, with no longitudinal enamel flutes, round, oval or gently compressed basal section, sharply pointed and eventually showing wrinkles on the base of the smooth cutting edges (morphotype 2). A specimen that clearly illustrates this transition is shown in figure 2: lingual face faintly sub-faceted (C1), labial one completely smooth $(\mathrm{C} 2)$, sharply pointed, and with a basal section gently compressed labio-lingualy $(\mathrm{H})$. 
Enamel fluting only on the lingual face of the tooth is a character observed in Baryonyx walkery (Charig \& Milner, 1997), but the absence of serrations on the cutting edges precludes the specimens here described to be referred to this genus.

Gradients may be interpreted as suggestive of intraspecific variation, but in this case the differences, when the extremes (morphotypes 1 and 2) are compared, are too significant to suppose that only one species is represented by the sample. Besides, morphotype 1 is currently attributed to known forms of spinosaurines, while morphotype 2 is firstly recorded in this work. Thus, it probably represents another large size species of Theropoda, still unknown by skeletal remains.

About the gradient observed, the following comments looks to be pertinent: closely related species may present characters that vary in a subtle manner that renders clear-cut
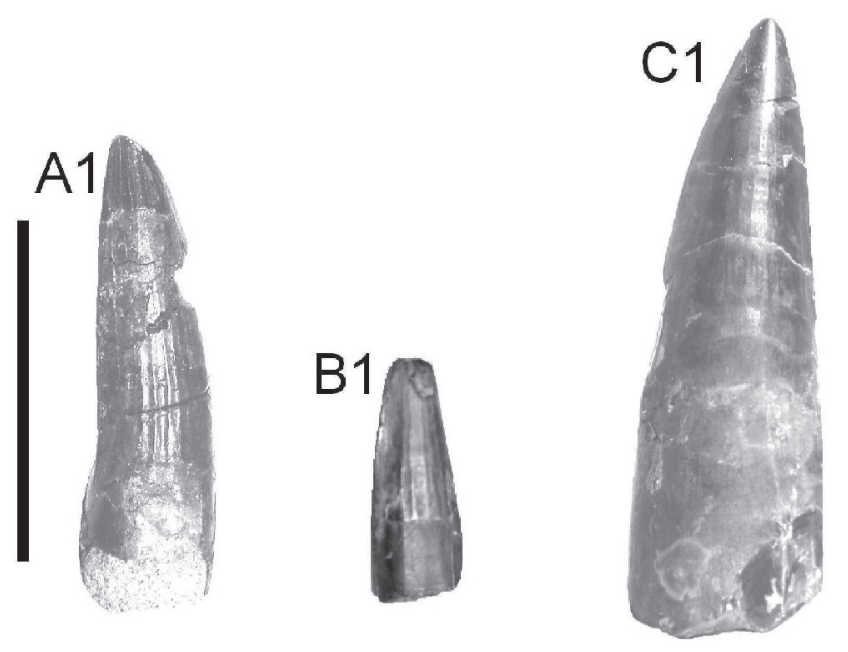

E1
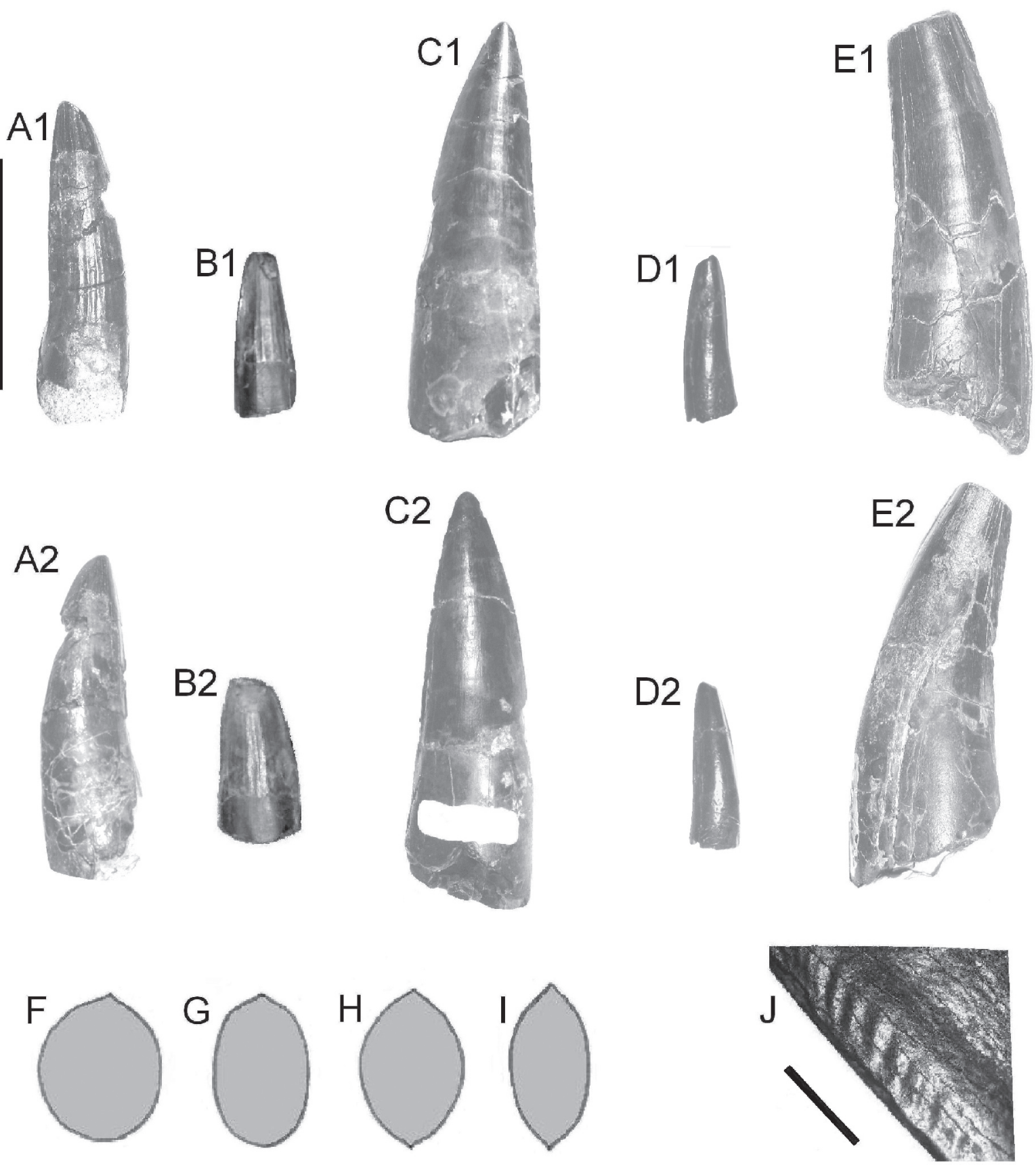

Figure 2. A-E, Teeth illustrating progressive morphologic modifications, including different sizes, from spinosaurine type, related as morphotype $1(\mathrm{~A} 1, \mathrm{~A} 2)$ to morphotype 2 (E1, E2), and the intermediaries morphologies (B1, B2, C1, C2, D1, D2); top and bottom teeth rows represent opposed faces of the same specimens, respectively; features of the teeth described in the text; F-I, teeth basal cross sections also related in the description; J, photomicrography showing carina basal wrinkles. Left superior scale bar $=5 \mathrm{~cm}(\mathrm{~A}-\mathrm{E})$; right inferior scale bar $=3 \mathrm{~mm}(\mathrm{~J})$. 
distinctions difficult. This may well be the case in the recorded sample from Laje do Coringa. If so, the sample of isolated teeth here described could actually represent at least two species of large sized theropod dinosaurs closely related. As the gradient clearly links both morphotypes, the possibility exists that morphotype 2 can represent a spinosaurine unknown form; smooth carina is a strong indicative of this interpretation. Besides, although several teeth with unserrated carinae and enamel surface smooth present labio-lingual compression in the basal section, others virtually identical show the sub-circular spinosaurine type. Actually, the degree of compression in morphoype 2 is quite variable, including those illustrated in Figures 2F, G, H and I.

The inference that a new spinosaurid form could have different dental features based solely on isolated teeth may look premature, but evidences recorded by a so large number of teeth found in the same outcrop should be considered. Among the teeth collected, morphotype 2 is much more frequent in the Laje do Coringa site than morphotype 1 (see above); it may have some thing to do with relative number of individuals in the paleocommunity.

The length reached by some teeth here described (in both morphotypes) indicates clearly that they belonged to animals comparable in size to the Albian-Cenomanian northern African Spinosaurus. Even if one chooses an alternative view, not assuming a spinosaurid affinity to the teeth included in morphotype 2, the evidence here discussed suggests that a new species of large sized theropoda, still unknown by skeletal remains, lived in the mid-Cretaceous of northeastern Brazil. The associated fauna collected along with the teeth sample here studied shows a paleocommunity similar to that recorded in Sahara, including the theropods Carcharodontosaurus, Sigilmassasaurus, and fresh water fishes - Mawsonia Mawson \& Woodward, 1907, Asiatoceratodus tiguidiensis (Tabaste, 1963), Ceratodus africanus Haug, 1905 (Vilas Bôas et al., 1999; Medeiros, 2001; Medeiros \& Vilas Bôas, 1999; Medeiros \& Schultz, 2001, 2002; Castro et al., 2004). Skeletal remains similar to those recorded by Laparent (1960) in Sahara are also found in Laje do Coringa (see Medeiros \& Schultz, 2001, 2002). In some, the taxonomic status remains unresolved.

\section{ACKNOWLEDGMENTS}

I thank my Biology pupils of UFMA, at São Luís, for help in long and hard fieldwork, and R. N. Santos Lemos, Entomologist of Agronomy Department of Universidade Estadual do Maranhão for microphotography here used. This study was undertaken with financial support of UFMA and Centro de Pesquisa de História Natural e Arqueologia do Maranhão. This paper was a contribution to the XIX Congresso Brasileiro de Paleontologia/VI Congresso Latino-americano de Paleontologia, held in August, 2005, in Aracaju (SE, Brazil).

\section{REFERENCES}

Aranha, L.G. de; Lima, H.P.; Souza, J.M.P. de \& Makino, R.K. 1990. Origem e evolução das bacias de Bragança-Viseu, São Luís e Ilha
Nova. In: G.P.R. Gabaglia \& E.J. Milani (eds.) Origem e evolução de bacias sedimentares, PETROBRAS, p. 221-233.

Bouaziz, S.; Buffetaut, E.; Ghanmi, M.; Jaeger, J.J., Martin, M.; Mazin, J.M. \& Tong, H. 1988. Nouvelles decouvertes de vertébrés fossiles dans l'Albien du sud tunisien. Bulletin de la Societé Géologique de France, 4(2):335-339.

Buffetaut, E. 1989. New remains of the enigmatic dinosaur Spinosaurus from the Cretaceous of Morocco and the affinities between Spinosaurus and Baryonyx. Neues Jahrbuch für Geologie und Paläontologie, Monatsheft, 1989(2):79-87.

Buffetaut, E. 1992. Remarks on the Cretaceous theropod dinosaurs Spinosaurus and Baryonyx. Neues Jahrbuch für Geologie und Paläontologie, Monatsheft, 1992:88-96.

Castro, D.F.; Toledo, C.E.V.; Sousa, E.P. \& Medeiros, M.A. 2004. Novas ocorrências de Asiatoceratodus (Osteichthyes, Dipnoiformes) na Formação Alcântara, Eocenomaniano da bacia de São Luís, MA, Brasil. Revista Brasileira de Paleontologia, 7(2):245-248.

Charig, A.J. \& Milner, A.C. 1997. Baryonyx walkeri: a fish-eating dinosaur from the Wealden of Surrey. Bulletin of the Natural History Museum, Geology Series, 53:11-70.

Corrêa Martins, F.J. 1997. A Laje do Coringa: um bone-bed da Formação Itapecuru (Cretáceo Superior da Bacia de São Luís - MA). Anais da Academia Brasileira de Ciências, 69(3):436-437.

Cunha, F.L.S. \& Ferreira, C.S. 1980. Um dipnoi na Formação Itapecuru (Cenomaniano), Maranhão, Brasil. In: CONGRESO ARGENTINO DE PALEONTOLOGÍA Y BIOESTRATIGRAFÍA, 2, 1980, 1. Actas, Buenos Aires, p. 1-9.

Dutra, M.F.A. \& Malabarba, M.C. S. L. 2001. Peixes do AlbianoCenomaniano do Grupo Itapecuru no Estado do Maranhão, Brasil. In: D.F. Rossetti; A.M. Góes \& W. Truckenbrodt (eds.) O Cretáceo da bacia de São Luís-Grajaú, Museu Emílio Goeldi, p. 191-208.

Góes, A.M. \& Rossetti, D. 2001. Gênese da bacia de São LuísGrajaú, Meio-Norte do Brasil. In: D.F. Rossetti; A.M. Góes \& W. Truckenbrodt. (eds.) O Cretáceo na bacia de São Luís Grajaú, Museu Emílio Goeldi, p. 15-29.

Haug, E. 1905. Paléontologie. In: F. Foureau (ed.) Documents scientifiques de la mission saharienne. Mission Foureau-Lamy "D'Alger au Congo par le Tchad 1904-1905", Masson \& Cie, p. 751-832.

Holz, M. 2003. Sequence stratigraphy as a tool for vertebrate taphonomy - an example from a Late Cretaceous dinosaur taphocenosis from São Luís basin, Northern Brazil. In: LATIN AMERICAN CONGRESS OF SEDIMENTOLOGY, 3, 2003. Abstracts, Belém, Museu Emílio Goeldi, p. 213-214.

Kellner, A.W.A. \& Campos, D.A. 1996. First Early Cretaceous theropod dinosaurs from Brazil with comments on Spinosauridae. Neues Jahrbuch fur Geologie und Palöontologie, Abhandlungen, 199(2):151-166.

Kellner, A.W.A. \& Campos, D.A. 2000. Brief review of dinosaur studies and perspectives in Brazil. Anais da Academia Brasileira de Ciências, 72(4):509-538.

Kellner, A.W.A. \& Mader, B.J. 1997. Archosaur teeth from the Cretaceous of Morocco. Journal of Paleontology, 71(3):525-527.

Lapparent, A.F. de 1960. Les dinosauriens du continental intercalaire du Sahara central. Memoires de la Société Géologique de France, N.S., 88A:3-56.

Machado, E.B. \& Kellner, A.W.A. 2005. Notas sobre Spinosauridae (Theropoda, Dinosauria). Anuário do Instituto de Geociências - UFRJ, 28(1):158-173.

Martill, D.M.; Cruickshank, E.; Frey, E.; Small, P.G. \& Clark, M. 1996. A new crested maniraptoran dinosaur from the Santana 
Formation (Lower Cretaceous) of Brazil. Journal of the Geological Society, 153:5-8.

Mawson, J. \& Woodward, A.S. 1907. On the Cretaceous Formation of Bahia (Brazil), and on vertebrate fossils collected therein. Quarterly Journal of the Geological Society of London, 63:128-139.

Medeiros, M.A. 2001. A Laje do Coringa (ilha do Cajual, bacia de São Luís, baía de São Marcos, MA): conteúdo fossilífero, bioestratinomia, diagênese e implicações na paleobiogeografia do meso-Cretáceo do nordeste brasileiro. Programa de Pós-Graduação em Geociências, Universidade Federal do Rio Grande do Sul, Tese de Doutorado, 134 p.

Medeiros, M.A. \& Schultz, C.L., 2001. Uma paleocomunidade de vertebrados do Cretáceo médio, bacia de São Luís. In: D.F. Rossetti; A.M. Góes \& W. Truckenbrodt (eds.) O Cretáceo na bacia de São Luís - Grajaú, Museu Emílio Goeldi, p. 209-221.

Medeiros, M.A. \& Schultz, C.L. 2002. A fauna dinossauriana da Laje do Coringa, Cretáceo médio do Nordeste do Brasil. Arquivos do Museu Nacional, 60(3):155-162.

Medeiros, M.A. \& Schultz, C.L. 2004. Rayososaurus (Sauropoda, Diplodocoidea) no meso-Cretáceo do norte-nordeste brasileiro. Revista Brasileira de Paleontologia, 7(2):275-279.

Medeiros, M.A. \& Vilas Bôas, I. 1999. Ocorrência de uma paleocomunidade continental do Cenomaniano (Cretáceo Superior) do Nordeste do Brasil. In: JORNADAS ARGENTINAS DE PALEONTOLOGÍA DE VERTEBRADOS, 15, 1999. Resúmenes, La Plata, UNLP, p. 18.

Pedrão, E.; Arai, M.; Carvalho, I.S. \& Santos, M.H.B. 1993. Palinomorfos da Formação Itapecuru - análise palinológica de uma amostra de superfície da Ponta do Farol, São Luís - MA. Rio de Janeiro, PETROBRAS, CENPES, 10 p. (Relatório Técnico)

Pereira, A.A. \& Medeiros, M.A. 2003. Novas ocorrências de peixes no Eocenomaniano do Maranhão. In: CONGRESSO BRASILEIRO DE PALEONTOLOGIA, 18, 2003. Boletim de Resumos, Brasília, SBP, p. 221.

Rossetti, D.F. \& Truckenbrodt, W. 1997. Revisão estratigráfica para os depósitos do Albiano - Terciário Inferior (?) na bacia de São Luís (MA), norte do Brasil. Boletim do Museu Paraense Emílio Goeldi (Série Ciências da Terra), 9:29-41.

Russell, D.A. 1996. Isolated dinosaur bones from the middle Cre- taceous of the Tafilalt, Morocco. Bulletin du Muséum National de Histoire Naturelle, Paris, $4^{a}$ Sér., 18, Section C (2-3): 349-402.

Sereno, P.C.; Beck, A.L.; Dutheil, D.B.; Gado, B.; Larsson, H.C.E.; Lyon, G.H.; Marcot, J.D.; Rauhut, O.W.M.; Sadleir, R.W.; Sidor, C.A.; Varricchio, D.D.; Wilson, G.P. \& Wilson, J.A. 1998. A long-snouted predatory dinosaur from Africa and the evolution of Spinosaurids. Science, 282:1298-1302.

Stromer, E. 1915. Ergebnisse der forschungsreisen Prof. E. Stromers in den Wüsten -Ägyptens. II- Wirbeltier-Reste der Baharîje-Stufe (unterstes Cenoman). 3 - Das original des theropoden Spinosaurus aegyptiacus nov. gen., nov. spec. Abhandlungen der Königlich Bayerischen Akademie der Wissenschaften, 28(3):1-32.

Stromer, E. 1931. Ergebnisse der forschungsreisen Prof. E. Stromers in den Wüsten -Ägyptens. II- Wirbeltier-Reste der Baharîje-Stufe (unterstes Cenoman). 10 - Ein skellet-rest Carcharodontosaurus nov. gen. Abhandlungen der Königlich Bayerischen Akademie der Wissenschaften, N.F., 9:1-23.

Sues, H.D.; Frey, E.; Martill, D.M. \& Scott, D.M. 2002. Irritator challengeri, a spinosaurid (Dinosauria: Theropoda) from the Lower Cretaceous of Brazil. Journal of Vertebrate Paleontology, 22(3):535-547.

Tabaste, N. 1963. Étude de restes de poisons du Crêtacé saharien. Mémoires IFAN, 68:437-485.

Taquet, P. \& Russell, D.A. 1998. New data on spinosaurid dinosaurs from the Early Cretaceous of the Sahara. Comptes Rendus del 'Academie des Sciences, Paris, Sciences de la Terre et des Planets, 327:347-353.

Vilas Bôas, I. \& Carvalho, I.S. 2001. Répteis marinhos (Mosasauria e Plesiosauria) do Cretáceo Superior da bacia de São Luís (Maranhão, Brasil). In: D.F. Rossetti; A.M. Góes \& W. Truckenbrodt (eds.) O Cretáceo na bacia de São Luís - Grajaú, Museu Emílio Goeldi, p. 223-233.

Vilas Bôas, I.; Carvalho, I.S.; Medeiros, M.A. \& Pontes, H. 1999. Dentes de Carcharodontosaurus (Dinosauria, Tyrannosauridae) do Cenomaniano, bacia de São Luís (norte do Brasil). Anais da Academia Brasileira de Ciências, 71(4):846-847.

Received in October, 2005; accepted in November, 2006 